\title{
Corrigendum
}

\section{Application of avian cytokines as immuno-modulating agents}

S. UMAR, M. ARIF, M.A.A. SHAH, M.T. MUNIR, M. YAQOOB, S. AHMED, M.I. KHAN, M. YOUNUS and M. SHAHZAD

doi:10.1017/S004393391500238X. Published online by Cambridge University Press, 2 December 2015.

The authors regret that an error was made in the author affiliations of the published paper (Umar et al., 2015). When originally published the affiliation of 'National Veterinary School of Toulouse, France' was added in error to the author information for S. Umar. The authors would like to apologize for this mistake.

\section{References}

UMAR, S., ARIF, M., SHAH, M.A.A., MUNIR, M.T., YAQOOB, M., AHMED, S., KHAN, M.I., YOUNUS, M. and SHAHZAD, M. (2015) Application of avian cytokines as immuno-modulating agents. World's Poultry Science Journal 71: 643-654. doi: 10.1017/S004393391500238X. 